\title{
Localisation of SDGs in Higher Education: Unisa's whole institution, all goals and entire sector approach
}

\author{
Godwell Nhamo, University of South Africa, South Africa
}

\begin{abstract}
This paper documents the processes leading to the hosting of the University of South Africa (Unisa) Sustainable Development Goals (SDGs) Localisation Indaba ${ }^{1}$ in November 2019. Of interest is how the programming, which started as a purely inreach community engagement project, ultimately embraced the whole institution, all SDGs and the South African higher education sector. Data was generated via two platforms, namely participatory action research and a survey evaluating the Indaba. The following cycles emerged: the development of a Unisa Management Policy Brief calling for the SDGs Localisation Indaba in 2017 (Cycle 1); the development of an SDGs for Society Research Stream as part of the Unisa Annual Interdisciplinary Academy and Summer School in 2018 (Cycle 2); and the SDGs Localisation Indaba in 2019 (Cycle 3). The Indaba led to the SDGs Localisation Declaration which resulted in the formation of the SDGs Liaison Committee. Several agreements were made to expand SDGs localisation at Unisa. Finally, the Indaba attracted many participants from outside Unisa, especially from other institutions of higher education. However, it took almost three years to realise the SDGs localisation dream at Unisa. The key recommendation is thus that those championing SDGs localisation should be prepared to continue moving forward despite delays due to management changes and processes.
\end{abstract}

Keywords: Higher education, sustainable development goals, domestication, localisation of the SDGs

\section{Introduction}

One positive outcome of the 2030 Agenda for Sustainable Development (AfSD) (United Nations, 2015) was a separate Sustainable Development Goal (SDG 4) focusing on quality education within the 17 SDGs (Nhamo, 2017). Institutions of higher education remain platforms to catalyse the implementation of all SDGs (Nhamo \& Mjimba, 2020). The mainstreaming of SDGs in institutions of higher education must involve management education. To this end, during the 2015 Global Forum for Responsible Management Education held in New York, the United Nations Principles for Responsible Management 
Education (PRME) signatories reaffirmed their support for the SDGs agenda (Parkes, Buono \& Howaidy, 2017).

Institutions of higher education have started localising the SDGs, including mainstreaming them in the traditional spaces of teaching and learning, community service and research, development and innovation. Other new areas of mainstreaming SDGs are emerging such as integrating SDGs into university strategies, mission statements and operations (Fleaca, Fleaca \& Maiduc, 2018; Paletta et al., 2020) and into what Filho et al. (2019) have termed the 'third mission', that is, mainstreaming into external stakeholder and society engagement platforms. Of importance is that there are obstacles to extending the implementation of the SDGs in institutions of higher education and many universities are lagging behind. A study involving 3495 academic staff from nine universities in southern Nigeria revealed that awareness of sustainability matters was the most critical stumbling block (Ukenna, Idoko \& Ogbari, 2018). With a student population of over 350000 and staff complement close to 5000 (Nhamo, 2020), Unisa needed to start raising awareness of and localising the SDGs.

Vladimirova and Le Blanc (2016) have explored the links between education and the SDGs in 37 flagship United Nations reports. They found that all but SDG 14 (oceans) had a link to education. However, if institutions of higher education are to play a central role in the implementation of the SDGs, some factors are critical. These include increasing publicly funded research and the development of a regional higher education SDGs partnership. The issue of partnerships is discussed later in this paper. Another shortcoming observed was the ad hoc manner in which the SDGs are being addressed in institutions of higher education. According to Franco et al. (2019, p. 161), the initiatives are "scattered and isolated" and cannot be implemented on the basis of a generic approach. Various regions in the world have different needs and are at different levels of engaging with the global goals agenda. El-Jardali, Ataya and Fadlallah (2018) suggested that a huge challenge lies ahead. They argued that the context in which universities currently operate has changed with the proclamation of the 2030 Agenda for Sustainable Development. This Agenda demands "a change in mind-sets and culture in both academia and government" in order to cope with the global challenge (El-Jardali et al., 2018, p. 2).

Based on the preceding discussion, universities across the globe (including Unisa) are becoming increasingly aware of the SDGs agenda and starting to take action, including the hosting of platforms and events aimed at raising awareness and making proclamations of commitment to the global development goals. The aim of this paper was to document the processes leading to the hosting of an SDGs Localisation Indaba at Unisa. The intention was to describe the lobbying and championing that took place during a three-year cycle from 2017 to November 2019, which resulted in the Unisa SDGs Localisation Declaration. Opportunities and challenges that emerged from the processes provide the basis for reflections and recommendations to potentially inform change initiatives in other contexts. 


\section{Literature survey}

More research is increasingly being conducted in the mainstream regarding the localisation of the SDGs in higher education institutions. Korhonen-Kurki et al. (2020) examined how the University of Helsinki was realising SDGs localisation and discovered that SDG 4 (Quality Education) was clearly significant for all the new initiatives in the core mandates of any university namely research, teaching, engaged scholarship and own operations. Other SDGs of importance to the University were SDG 17 (Partnerships) and SDG 3 (Health and Wellbeing). The SDGs that did not feature prominently were SDG 1 (No Poverty), SDG 6 (Clean Water and Sanitation) and SDG 5 (Gender Equality). In their conclusion, KorhonenKurki et al. (2020) expressed concern that the omission of some of the SDGs could result in the questioning of the University's commitment to global goals. The view was that the SDGs in the periphery should form part of the new strategic planning of the University of Helsinki for a global impact.

According to Bartlett, Popov and Ruppert (2020), when the curriculum focuses on sustainability competencies and searches for best practices, this is better addressed by teaching the SDGs. SDGs case studies were deemed to be a method to connect all the dots, thereby promoting an understanding of the complex sustainability challenges facing the world today. One typical challenge is climate and global change. African scholars Zhou et al. (2020) mentioned the dimension of raising awareness among key university stakeholders, including academic and non-academic staff, students and labour movements. The authors then highlighted that universities will also require learning hubs that focus specifically on SDG activities. Faculties and departments were challenged to review their curricula aimed at mainstreaming aspects of the SDGs in both under- and postgraduate programmes. According to Zhou et al. (2020), such curriculum reform should be part of the broader agenda of African universities to transform higher education teaching and research. When SDGs are an integral element of the curriculum, this promotes "interdisciplinary and transdisciplinary work, positively transform[ing] their moral and ethical path in life and research agenda to inform policy and practice" (Ketlhoilwe, Silo \& Velempini, 2020, p. 124). In a review of 60 articles focusing on higher education for sustainable development across the world, Franco et al. (2019) identified the targeted SDGs and those with gaps. The findings are summarised in Table 1 below.

Table 1: Higher education and SDG coverage

\begin{tabular}{|l|l|l|l|l|}
\hline Coverage/Region & Americas & Asia and the Pacific & Africa & Europe \\
\hline Targeted SDGs & $\begin{array}{l}2,3,4,6,7,8,9, \\
10,11,12,13,15, \\
16 \text { and } 17\end{array}$ & $\begin{array}{l}1,4,5,6,7,8,11,12, \\
13,14,15,17\end{array}$ & $4,5,7,11,12$ and 15 & $\begin{array}{l}4,6,7,9,11,12,13, \\
14,15,16 \text { and } 17\end{array}$ \\
\hline SDGs with gaps & 1,5 and 14 & $2,3,9,10$ and 16 & $\begin{array}{l}1,2,3,6,8,9,10,13, \\
14,16 \text { and } 17\end{array}$ & $1,2,3,5,8$ and 10 \\
\hline
\end{tabular}

Source: Author, based on Franco et al. (2019, pp. 1632-1635) 
The data in Table 1 underscores the earlier observation that there is diversity in the manner in which higher education institutions are approaching the SDGs across the world. SDGs 4 (Quality Education), 7 (Sustainable Energy), 11 (Sustainable Settlements), 12 (Sustainable Consumption and Production) and 15 (Biodiversity) are commonly targeted by higher education institutions across the regions (Franco et al., 2019). There are gaps in addressing SDGs 1 (Ending Poverty), 2 (Sustainable Agriculture), 3 (Sustainable Health) and 10 (Reducing Inequality). Only three SDGs, namely 1 (Ending Poverty), 5 (Gender) and 14 (Oceans), were perceived as gaps in the Americas.

In order to transfer the reform agenda of the SDGs to the university space, Ketlhoilwe et al. (2020) highlighted workshops and seminars as excellent conduits. Projects should also be identified; Stellenbosch University in South Africa has identified 254 potential projects for implementation in line with the 17 global goals. Zhou et al. (2020) highlighted the dimension of collaboration between various higher education institutions from the developed northern hemisphere and the developing southern hemisphere. Such collaborative partnerships are believed to harness collective intelligence, resulting in shared problem solving (Ketlhoilwe et al., 2020). Kupika, Mbereko and Chinokwetu (2020) extended the debate by describing how Chinhoyi University of Technology in Zimbabwe was addressing Climate Action (SDG 13). Their findings were as follows: "Despite its wide efforts, the university still needs to introduce optional modules, extra qualifications, and additional learning course[s] which can be taken by both students and staff to understand climate change across all disciplines" (p. 108). Paul (2020, p. 131) introduced the concept of university 'environmental hackathons' aimed at furthering the SDGs, particularly SDG 13. Hackathons are defined as "time-intensive events focused on solving real-world problems". The implementation of an SDG 13-focused hackathon revealed that students have the potential to develop technology and ideas for climate change adaptation and mitigation.

Universities are potentially agents of change and social impact, particularly in the communities in which they work (Villa et al., 2020). To this end, as universities localise SDGs, they should not neglect their role in engaging the communities. According to Mataix et al. (2020), this is an element that has emerged clearly in fostering urban innovation in the city of Madrid, Spain. The approach jointly identifies the challenges and needs of the city and then tests them using university facilities. On the basis of this, prototypes are developed and pilot-tested in the city. In the Madrid project, the authors learnt several lessons, including the importance of the creation of both an online and offline space for collaboration, building relationships between stakeholders that promote an enabling environment for active participation and engagement with citizens, and incorporating cultural dimensions. The inclusion of citizen science links collaborative projects, which the SDG space requires, given the demand for Big Data use (DITOS Consortium, 2017; Ketlhoilwe et al., 2020).

Weybrecht (2017) has focused on the PRME space occupied by business schools. The author sees challenges and opportunities presented to management education by the SDGs. Business schools were viewed as not having reached their full potential in moving the 
SDGs forward. Business schools were challenged to make choices and decide if they would "do nothing and risk disappearing or being replaced" (Weybrecht, 2017, p. 92). They were challenged to assume the responsibility and embrace the SDGs jointly as faculty members and students. This should transform management education positively into a path towards and powerful tool for reaching the SDGs and producing future business leaders who can make the world a better place. Integrating SDGs into the business school curriculum has started. One Brazilian business school achieved this by acknowledging that a considerable mind-set shift would be needed for sustainability leadership (De Paula Arruda Filho, Hino \& Beuter, 2019). Along similar lines, Kopnina (2018) reviewed the teaching of SDGS in The Netherlands in vocational colleges, and at both under- and postgraduate university level. The results showed how curricula aimed at raising awareness of SDGs guided students towards developing "a certain degree of critical, imaginative, and innovative thinking about sustainable development in general and the SDGs in particular" (p. 1268).

Rogers (2019) focused on the role of second-generation non-formal education and how this may be utilised to operationalise the SDGs through community learning centres. The author's argument is that adult learning targets that are evident throughout all 17 SDGS cannot be reached through formal learning programmes alone. To this end, an expanded non-formal education programme is needed, and institutions of higher learning remain relevant in this space.

The next section focuses on the methodology used to generate and analyse data for this paper.

\section{Methodology}

Participatory action research and a survey were used to generate data for this research. Participatory action research in community engagement and/or engaged scholarship research in higher education institutions is certainly not new (see, for example, Nhamo, 2012; McAteer \& Wood, 2018; Ryan \& Squires, 2019; Wood, 2019; Nhamo, 2020). It involves the researcher engaging with the researched phenomena, with a view to finding practical solutions to emerging problems (Nhamo, 2012). This usually comes in continuous cycles that may take several years. The overall objective was to determine and document the processes leading to and including the Unisa SDGs Localisation Indaba and Declaration. Participants were given a survey both on site during the Unisa Indaba on 29 November 2019, and offsite following the Indaba. Three distinctive phases of problem identification and solving relating to the global SDGs emerged. The cycles were as follows: the development of a Unisa Management Policy Brief calling for an SDGs Localisation Indaba in 2017 (Cycle 1); the development of an SDGs for Society research stream for the Unisa Annual Interdisciplinary Academy and Summer School in 2018 (Cycle 2); and the hosting of the SDGs Localisation Indaba in 2019 (Cycle 3).

In the survey, participants were asked to comment on several key matters. These included ranking parts of the SDGs Localisation Indaba programme including Unisa's Vice Chancellor and Principal presenting the welcome and opening speech; the launch of the 
books, The Green Building Evolution and Sustainable Development Goals and Institutions of Higher Education; a panel discussion on the localisation of the SDGs; SDGs localisation in IHE main talk; the breakaway sessions in general; the plenary feedback session; and Unisa management's reading of the Unisa SDGs Localisation Declaration. Other survey questions requested participants to express their views on whether the concept of SDGs localisation in higher education was one that all universities in South Africa and worldwide should implement; whether the participants' institutions (higher education or not) had localised the SDGs; the participants' familiarity with the United Nations document Transforming our World: The 2030 Agenda for Sustainable Development, prior to attending the Unisa Indaba; the number of SDGs Localisation workshops, seminars, conferences, symposiums and/or platforms attended prior to the Unisa Indaba; the source of attraction to participate in the Indaba; and rating on a scale of 1 (not achieved) to 10 (achieved) whether the participants' expectations and objectives of the Indaba had been met. The use of surveys is common in research of this kind (see, for example, Simsekoglu \& Klöckner, 2019; Wu et al., 2019). In total, 150 people attended the Indaba. Of these, 72 (48\%) completed the survey. The demographics and other general details of the respondents are presented in Figures 1 and 2 below.

Figure 1: Demographics of the respondents $(n=72)$. Source: Author

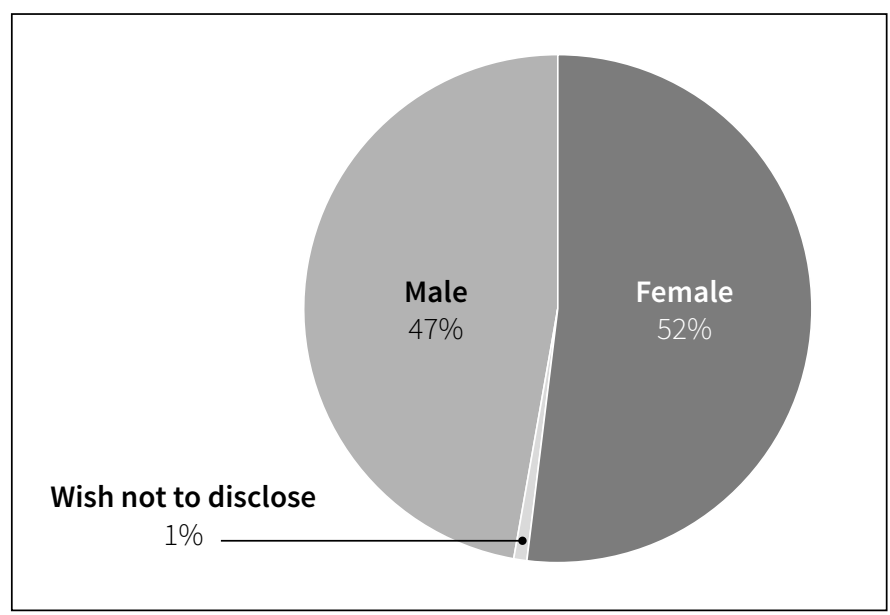


Figure 2: Respondents' age groups ( $n=72)$. Source: Author

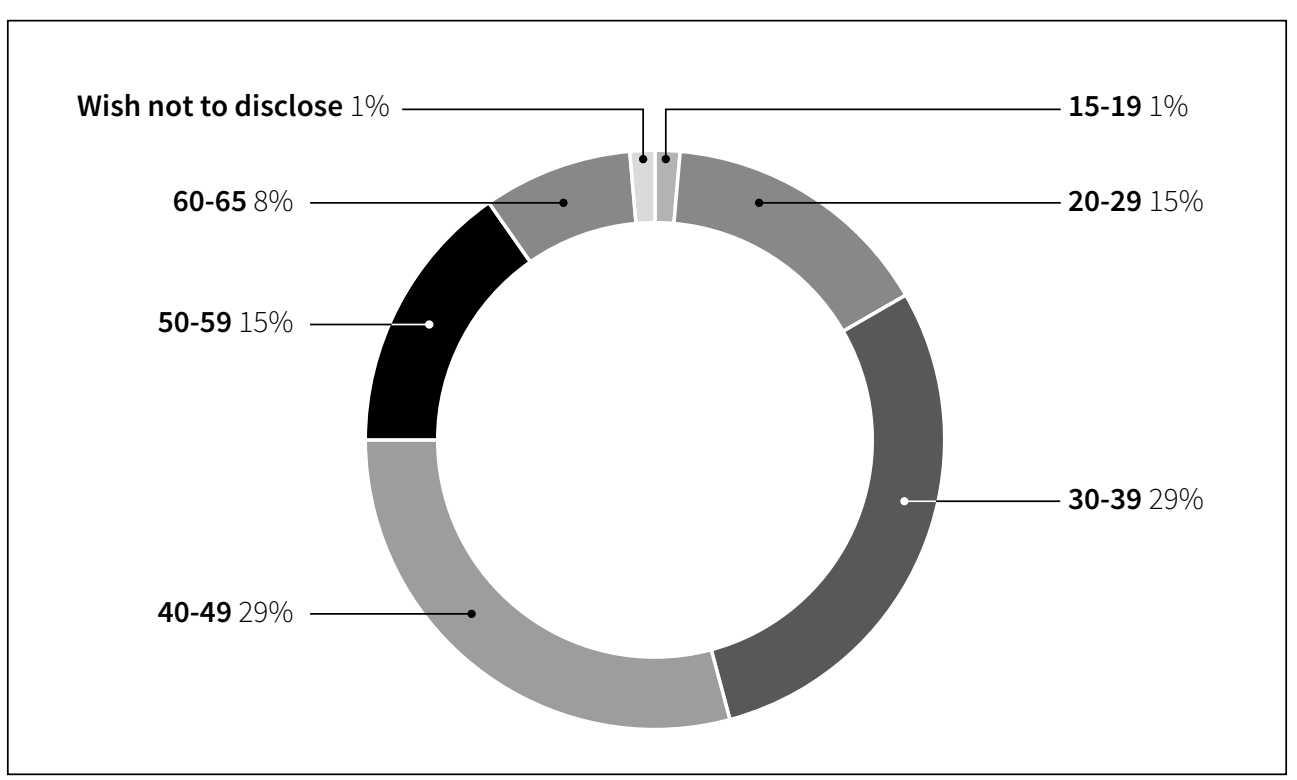

The details of the key findings from both the participatory action research and the survey are discussed in the next section. Conclusions are then drawn and recommendations made.

\section{Presentation and discussion of findings}

This section is divided into the various previously identified cycles in the participatory action research cycles.

\section{Cycle 1: Development of a policy brief on the SDGs Localisation Indaba}

On 15 April 2017, the researcher emailed the Unisa Vice Chancellor and Principal, Professor Mandla Makhanya, copying three other officials according to protocol, regarding a proposal for a one-day Indaba on SDGs domestication at Unisa and sharing a draft of a short policy brief. The Vice Chancellor had supported efforts on sustainability since 2011 (Nhamo, 2020) and his response was encouraging. The entry point of a policy brief mirrors Van Staden's (2020) observation of the need for actors to initiate micro innovations, which unlock value in macro innovations within institutions when addressing sustainability matters. Such innovations would also look back to when higher education institutions committed to embrace sustainable development during the Copernicus Declaration of 1994 (Farinha, Caeiro \& Azeiteiro, 2019).

Several issues were raised regarding the two-page policy brief of 15 April 2017. In the preamble, the policy brief indicated that it sought to work with Unisa MANCOM and requested approval to host a one-day Indaba on the Domestication and Localisation of SDGs 
in Higher Education, with the aim of kick starting Unisa in this endeavour. The broader goal was to continue supporting Unisa's vision to be "the African university shaping futures in the service of humanity". In addition, it was highlighted that embarking on a systematic domestication and localisation of SDGs at Unisa would elevate Unisa to the position of a national, and possibly continental, trailblazer in implementing the 2030 Agenda for Sustainable Development and its 17 SDGs from both an administrative and academic perspective. Rephrasing the 2030 Agenda's battle cry, the policy brief proposed Unisa's rallying point as "UNISA must NOT BE LEFT BEHIND" (upper case used for emphasis).

The rationale for the SDGs Domestication and Localisation Indaba was also spelled out in the policy brief. This included highlights on emerging global trends that were shaping how higher education ought to respond to the SDGs in order to remain relevant to their communities in general, and development agendas in the 21st century, specifically. The following agendas were highlighted: the 2030 Agenda for Sustainable Development of 2015, the Global Reporting Initiative's Sustainability Standards of 2016 and the Paris (Climate Change) Agreement of 2015.

The policy brief further provided background on the SDGs, indicating that they had come into effect in January 2016 as an expanded global development agenda for all countries. It noted that the 17 SDGs and 169 targets were to be cascaded from the global, to the continental, subcontinental and national levels (domestication), and to state/province, local government, higher education, the corporate sector and many other spatial scales for implementation (localisation). To this end, Unisa had to understand the various ways in which the SDGs and their targets are or can be implemented at an institutional level. The policy brief further highlighted that linked to the domestication and localisation of the SDGs was the implementation of other global, continental and national agendas. On the continental and national scales, institutions like Unisa were to be responsive to the Africa Agenda 2063 finalised by the African Union in 2014 and South Africa's National Development Plan (NDP) Vision 2030, which was finalised in 2012. The policy brief made it clear that both Agenda 2063 and the NDP were mirrored in the 2030 Agenda for Sustainable Development, making it essential for all higher education work in the next 14 years and beyond to urgently respond to the 2030 Agenda as a proxy for other continental and national visions.

The purpose of the Indaba was set out in the policy brief: to map the way forward to domesticate and localise the 2030 Agenda for Sustainable Development at Unisa in the context of other supporting and competing programmes. The objectives were to:

- Raise greater awareness across Unisa about the 2030 Agenda, especially the 17 SDGs, related targets and indicators, as well as the role of higher education (specifically Unisa) in their implementation;

- Allocate institutional roles and responsibilities to both the administrative (nonacademic) and academic structures in engaging with the 17 SDGs as Unisa; 
- Galvanise Unisa to be part of the global drive to implement the 2030 Agenda, including assisting communities to measure, report and verify progress towards meeting the objectives of this global agenda; and

- Explore ways to assist other institutions of higher learning in engaging with the 2030 Agenda for Sustainable Development.

The programme for the day included presentations and breakaway sessions. Topics for discussion are indicated in Box 1 below.

\section{Box 1: SDGs Domestication and Localisation Indaba Programme. Source: Author}

- The role of higher education in the 2030 Agenda for Sustainable Development (Vice Chancellor and Principal, Unisa)

- Understanding the 2030 Agenda for Sustainable Development and the call for domestication and localisation (Exxaro Chair, Unisa)

- The interface between the National Development Plan, Africa Agenda 2063 and SDGs (National Department of Monitoring and Evaluation)

- Measurement, reporting and verification in the SDGs era (Statistics South Africa)

- Drawing up interlinkages between the SDGs, Global Reporting Initiative Sustainability Standards and the UN Global Compact (Sustainability Office Representative)

Following a presentation of the policy brief to the Unisa Management Committee (MANCOM) on 1 June 2017, revisions were made before a second draft was presented to the Acting Vice Principal. Preparations for an Indaba went ahead including invitations to the Minister of Higher Education and Training and other government officials. Despite their enthusiasm, the hosting of the Indaba had to be postponed.

Internal organisational dynamics can have negative consequences in terms of scheduling and planning events. Both Van Staden (2020) and Akins II et al. (2019) have written on these barriers. It was important for the institutional system to understand what Van Staden (2020) called the micro-level innovation. Drawing from Kennesaw State University, and through the application of the process model in change management, Akins II et al. (2019) found that self-determination was the most important way to advance sustainable development in higher education institutions, especially by middle-level managers. In the Unisa case, the author became a middle-manager level change driver, which eventually resulted in top management buy-in to SDGs localisation.

In an institution as big as Unisa, many events take place concurrently and it was important that the Indaba did not clash with a larger or top management event. In this instance, the planning would ultimately involve all university structures, including the 
students. From Akins II's et al. (2019) observation, three types of institutional barriers to sustainability education and organisational change in higher education institutions should be addressed: awareness, resources and structural barriers. One of the matters regularly raised by Unisa management concerned resources for implementing the proposed SDGs localisation. The author had to reassure management that the Exxaro Chair in Business and Climate Change, to which he was incumbent, would lead the way in awareness raising and be responsible for topping up human resources as required. Unisa's concern is a valid one because capacity to address sustainability related matters and implement projects is still limited in higher education institutions from the global south (Alejandro-Cruz et al., 2019).

The Indaba was planned for 9 October 2017. It was postponed to 21 February 2019 and finally took place only on 29 November 2019. The postponements and struggle to confirm a date was extremely disappointing to the author who thus went into 'hibernation'. This was compounded by staff movements in the office of the Vice Principal: Strategy, Risk and Advisory Services. As a scholar with an interest in the SDGs and sustainability matters at Unisa, the author had developed a cordial relationship with the former Vice Principal of this portfolio, over the years from 2011 until 2017. With the changes in staff, a relationship had to be developed with the new portfolio manager, who came into office in the last quarter of 2017.

Based on Verhulst and Boks (2014) and Akins II et al. (2019), a few indicators were qualitatively and subjectively assessed in relation to two of the three barriers identified earlier. The results are portrayed in Table 2. Dedeurwaerdere (2013, p. 3783) had noted that many of these barriers cannot be "removed without far-reaching institutional change" and this may even require a new set of indicators to be established (Findler et al., 2019). Hence, Dedeurwaerdere's suggestion for an "incremental institutional change approach, based on a gradual institutionalisation process of existing initiatives" (2013, p. 3783) as there could also be value disruptions leading to a new institutional equilibrium (Milchram et al., 2019). Moving Unisa to reduce its carbon footprint, for example, would imply moving to renewable energy, re-thinking the nature of travel, re-orienting teaching and new infrastructure development. To some extent, this is what happened at Unisa with the move towards sustainability starting back in 2007 when the university ratified the United Nations Global Compact; associated progress is reported every two years. However, with regard to SDGs localisation, Kioupi and Voulvoulis (2019, p. 6104) maintained that "the interconnectedness of the SDGs and the complexity of sustainability as a concept make it difficult to relate the SDGs to educational learning outcomes". This draws attention to the concept of institutional work that focuses on the roles and responsibilities of key actors (Beunen \& Patterson, 2019), work that is both political and often contested. 
Table 2: An assessment of selected change barriers to SDGs localisation at Unisa. Source: Author

\begin{tabular}{|c|c|c|c|}
\hline Barrier & Indicator & Significance & Comment \\
\hline \multirow[t]{4}{*}{$\begin{array}{l}\text { Lack of } \\
\text { awareness }\end{array}$} & $\begin{array}{l}\text { Lack of interest and involvement } \\
\text { of the majority of the students } \\
\text { and staff members }\end{array}$ & High & $\begin{array}{l}\text { This was high, and is complicated by } \\
\text { students being off campus. }\end{array}$ \\
\hline & $\begin{array}{l}\text { Lack of support by top } \\
\text { management, including the } \\
\text { college deans }\end{array}$ & Low & $\begin{array}{l}\text { Not pronounced. There was } \\
\text { considerable support, with the Vice } \\
\text { Chancellor at the forefront. }\end{array}$ \\
\hline & $\begin{array}{l}\text { Lack of policy making in order } \\
\text { to promote sustainability }\end{array}$ & Low & $\begin{array}{l}\text { Unisa has adequate policies } \\
\text { promoting sustainability, including } \\
\text { being a signatory to the United } \\
\text { Nations Global Compact. }\end{array}$ \\
\hline & $\begin{array}{l}\text { Lack of recognition, and } \\
\text { change agents for sustainability } \\
\text { and SDGs localisation are often } \\
\text { not taken seriously }\end{array}$ & Low & $\begin{array}{l}\text { Unisa recognises change } \\
\text { agents, including establishing a } \\
\text { sustainability office in the Vice } \\
\text { Chancellor's office in } 2012 \text {. }\end{array}$ \\
\hline \multirow[t]{4}{*}{$\begin{array}{l}\text { Lack of } \\
\text { resources }\end{array}$} & $\begin{array}{l}\text { Lack of money, with } \\
\text { sustainability and SDGs } \\
\text { localisation not seen as a } \\
\text { priority for funding }\end{array}$ & Low & $\begin{array}{l}\text { Unisa has dedicated resources } \\
\text { towards sustainability, including } \\
\text { retrofitting buildings to be greener } \\
\text { (rooftop solar installations, } \\
\text { rainwater harvesting etc.). }\end{array}$ \\
\hline & $\begin{array}{l}\text { High work pressure and lack } \\
\text { of time, with sustainability } \\
\text { and SDGs localisation often } \\
\text { combined with other tasks }\end{array}$ & High & $\begin{array}{l}\text { This remains true. For example, my } \\
\text { involvement remains part-time, as } \\
\text { with other staff (both teaching and } \\
\text { non-teaching). }\end{array}$ \\
\hline & $\begin{array}{l}\text { Lack of access to information, } \\
\text { due to absence of measuring } \\
\text { instruments or unwillingness } \\
\text { of staff }\end{array}$ & High & $\begin{array}{l}\text { This has been experienced from } \\
\text { Unisa Estate as data on energy and } \\
\text { water consumption is incomplete } \\
\text { when requested. The Estate } \\
\text { department also often indicates } \\
\text { lack of capacity. }\end{array}$ \\
\hline & $\begin{array}{l}\text { Lack of qualitative and } \\
\text { quantitative performance } \\
\text { indicators }\end{array}$ & High & $\begin{array}{l}\text { Indicators are being refined, } \\
\text { particularly as Unisa is now } \\
\text { involved in Time Higher Education } \\
\text { indices, as well as the United } \\
\text { Nations Global Compact. }\end{array}$ \\
\hline
\end{tabular}

For the purposes of this study, only the change barriers of lack of awareness and lack of resources were assessed (see Table 2). Though they could not be assessed at Unisa due to lack of data, indicators associated with structural barriers remain fundamental and should be investigated in future work. 


\section{Cycle 2: The development of the SDGs for Society research stream}

While what has been documented above was taking place, in December 2018 the coordinator of the Unisa Annual Interdisciplinary Academy and Summer School approached the author to develop a new research stream, the Society Research Stream (in relation to SDGs for Society). The Annual Interdisciplinary Academy was organised in conjunction with other major events during 2019. The main participants were Unisa students with the aim of developing their research, writing and publishing skills. Given that the SDGs for Society is the subject of another potential publication, discussion thereof will be left at this high-level engagement.

Through theSDGs for Society engagements, publiclectures and collegelevel presentations were made. These included a public lecture during the first Annual Interdisciplinary Academy and a Unisa College of Economic Management Board presentation. Other public lectures included one at the University of Botswana 19, another at the University of Zimbabwe and the final lecture in the 2019 series at the Africa Capacity Building Foundation in Harare. An estimated 600 students, staff and members of the public were reached during these engagements. More engagements in 2020 took the form of presentations to seven colleges ${ }^{2}$ within Unisa. Momentum was returning; the engagements in the research stream rekindled the author's aspirations to host the Unisa SDGs Domestication and Localisation Indaba.

In April 2018, the author wrote to all MANCOM top officials on "The use of SDGs in global university ranking and reporting". This was informed by the author's ongoing research linked to the SDGs and the Times Higher Education (THE) universities ranking initiative. One of the Vice Principals responsible for Research, Postgraduate Studies, Innovation and Commercialisation offered support in an email copied to all the MANCOM top officials, infusing new energy and the mandate necessary to take the project further. Contributing to further momentum towards the Indaba, was Unisa's decision on 6 December 2019 to respond to the THE Impact Rankings 2020 with an inaugural report submitted online on 6 January 2020.

The next section focuses on the SDGs Localisation Indaba held on 29 November 2019 (Cycle 3) and its subsequent evaluation by participants.

\section{Cycle 3: The SDGs Localisation Indaba}

On 29 November 2019 the Unisa SDGs Localisation Indaba, originally scheduled for October 2017, finally took place following a revival of the vision with MANCOM. Several recommendations and insights emerged during three breakaway sessions for the academic, non-academic and student groups respectively. The key points emanating from the nonacademic (operations) group are highlighted in Box 2 . 


\section{Box 2: Unisa SDGs Indaba non-academic discussion report-back. Source: Author}

There is a need to:

- Integrate the SDGs into roles and key performance areas

- Make individuals responsible for and reward them for delivering on SDGs

- Operationalise SDGs and focus on impact

- Develop capacity and create platforms for SDGs impact

- Put systems, processes and procedures in place

- Obtain accessible and reliable data, especially 'Big Data'

- Revitalise information centres like libraries - focusing on some of the quick, simple and 'big' wins

- Use own buildings as leading examples, and use this to create awareness

- Add other higher institutions of learning as critical stakeholders

- Grow own social capital - greater collaboration across universities, departments, and across local government, etc., sharing best practice and lessons learnt

Drawing on what transpired on 29 November 2019, the Unisa SDGs Localisation Declaration was produced. The latter and Indaba participant responses are discussed next.

\section{The Unisa SDGs Localisation Declaration}

This Declaration was the key output of the Indaba. Carefully crafted to be all encompassing, yet voluntary, the preamble makes reference to the following:

- Global agreements of relevance to the SDGs Indaba;

- Africa Union and Southern African Development Community (SADC) treaties and protocols;

- National acts and policies of relevance; and

- Unisa policies and strategic documents of relevance to the SDGs Indaba.

The main elements of the Unisa SDGs Localisation Declaration are set out in Box 3. 
Box 3: Major provisions of Unisa's SDGs Localisation Declaration. Source: Unisa, 2019, pp. 3-4

- Further strengthen the concept of sustainable development and sustainability to form part of the institutional DNA and find resonance in Unisa's vision and mission statements;

- Undertake to address all the SDGs through the implementation of the Sustainability Framework 2020 from operational, research, development and innovation, teaching and learning, as well as community engagement and outreach perspectives;

- Undertake to prioritise and fast track at corporate level, by means of the Sustainability Framework 2020, the implementation of the relevant targets;

- Commit to establishing a multi-stakeholder SDGs Liaison Committee cochaired by the Exxaro Chair in Business and Climate Change, the Director of the Sustainability Office as representative of the Vice-Principal (VP): Strategy, Risk and Advisory Services and one supported from any college that is already a champion in the SDGs space and was identified prior to or during the SDGs Indaba;

- Propose that the SDGs Liaison Committee members be SDGs Champions drawn from all relevant key entities that include college representatives, facilities management, other support departments at Unisa and selected representatives from VPs not already covered, and up to five outside recognised champions on SDGs implementation;

- Submit quarterly reports to the Social and Ethics Committee of Council to focus on progress against the implementation of the Sustainability Framework 2020;

- Exxaro Chair in Business and Climate Change to continue with college level engagements to raise awareness of SDGs and how this Declaration will be rolled out and implemented;

- Resource the Sustainability Office as appropriate to scale up the implementation of action plans that will emerge from this SDGs Localisation Declaration;

- No Unisa staff member and student should be left behind in the SDGs localisation and engagement programme;

- Consider any other appropriate alignments and reporting on SDGs with a view to instituting Unisa's Voluntary Reviews as part of existing reporting processes with no obligations to any outside body but solely for Unisa's internal monitoring, reporting and verification purposes.

In the Unisa SDGs Declaration, 12 SDGs were identified for management purposes: SDG 3 (Good Health and Wellbeing); SDG 4 (Quality Education); SDG 5 (Gender Equality); SDG 6 (Clean Water and Sanitation); SDG 7 (Affordable and Clean Energy); SDG 8 (Decent 
Work); SDG 10 (Reduced Inequality); SDG 11 (Sustainable Cities and Communities); SDG 12 (Sustainable Consumption and Production); SDG 13 (Climate Action); SDG 16 (Peace, Justice and Strong Institutions); and SDG 17 (Partnerships on the SDGs). However, there was consensus that all the 17 SDGs should remain relevant for the academic programme that enshrines research, teaching and learning, as well as service to the community.

\section{SDGs Localisation Indaba participant responses}

The respondents ( $56 \%$ of whom were in full-time employment, $32 \%$ in contract employment and $11 \%$ in an 'other' category) were asked to evaluate on a scale of 1 to 10 ( 1 = not useful, and 10 = very useful) how useful they found various parts of the SDGs Indaba. The findings are shown in Figure 3. It emerged that the participants were impressed with the SDGs Indaba with all seven segments rated above 8 out of a possible 10 points. On average, the rating was 8.5 . The most useful segment, according to the participants, was the reading of the Unisa SDGs Declaration. This possibly signifies the participants' expectations of action after such gatherings. Tied in second place were the plenary feedback and breakaway sessions.

Figure 3: Usefulness aspects of the SDGs Indaba (n=72). Source: Author

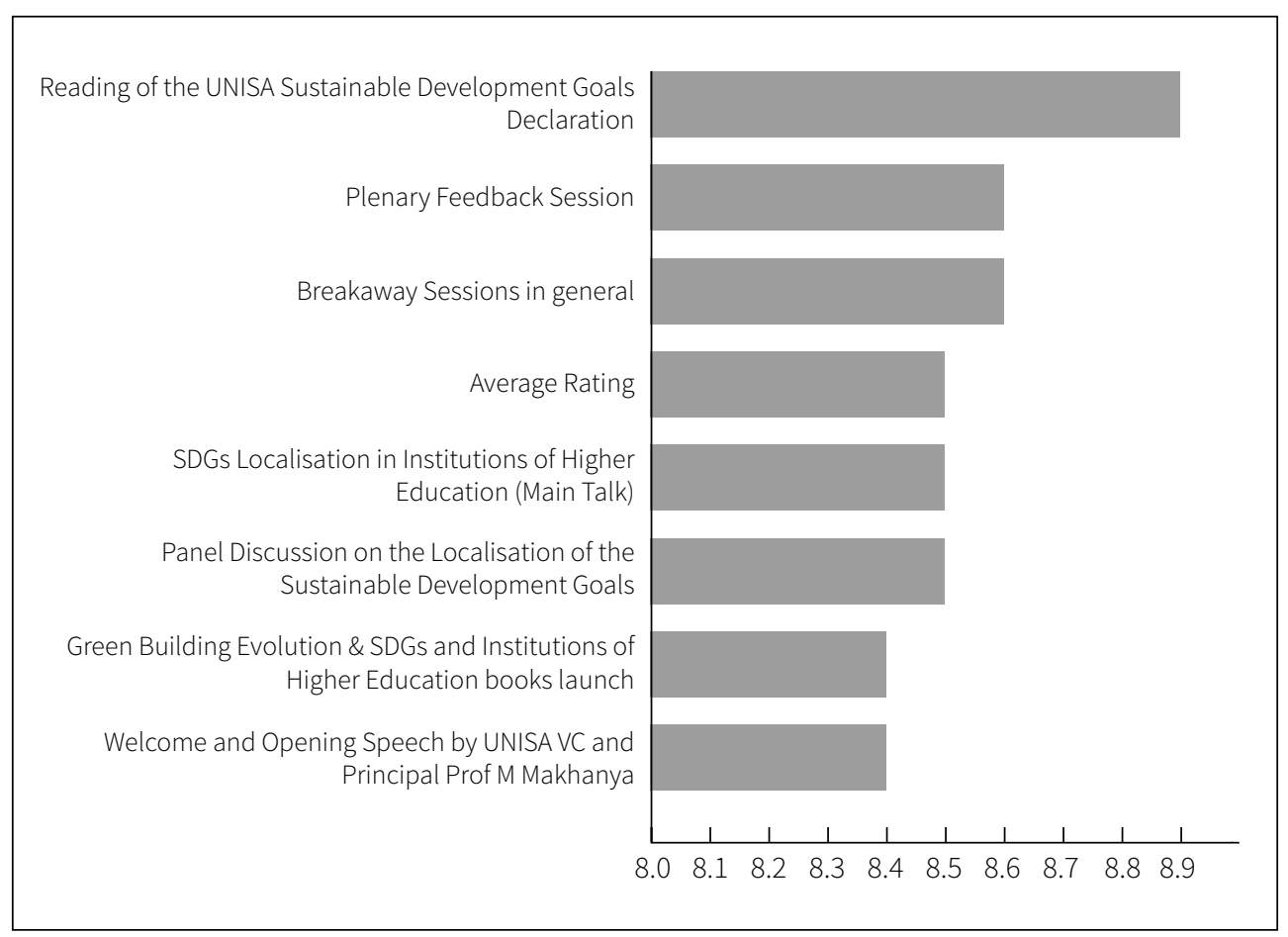


Participants were also asked to indicate (three aspects only) what had attracted them most to participating in the Unisa SDGs Indaba. The results are provided in Figure 4. The most popular was the theme of the Indaba and the desire to learn more (33\% of the responses), followed by the fact that the Indaba was aligned with work in which the participant was already involved (17\%). The launch of the two books and the desire to check out what other organisations were doing were additional pull factors. When asked to rate on a scale of 1 (not achieved) to 10 (achieved), whether the participants' expectations and objectives had been met, the result was 8.1 out of 10 possible points.

Figure 4: Attraction to the Unisa SDGs Indaba $(n=72)$. Source: Author

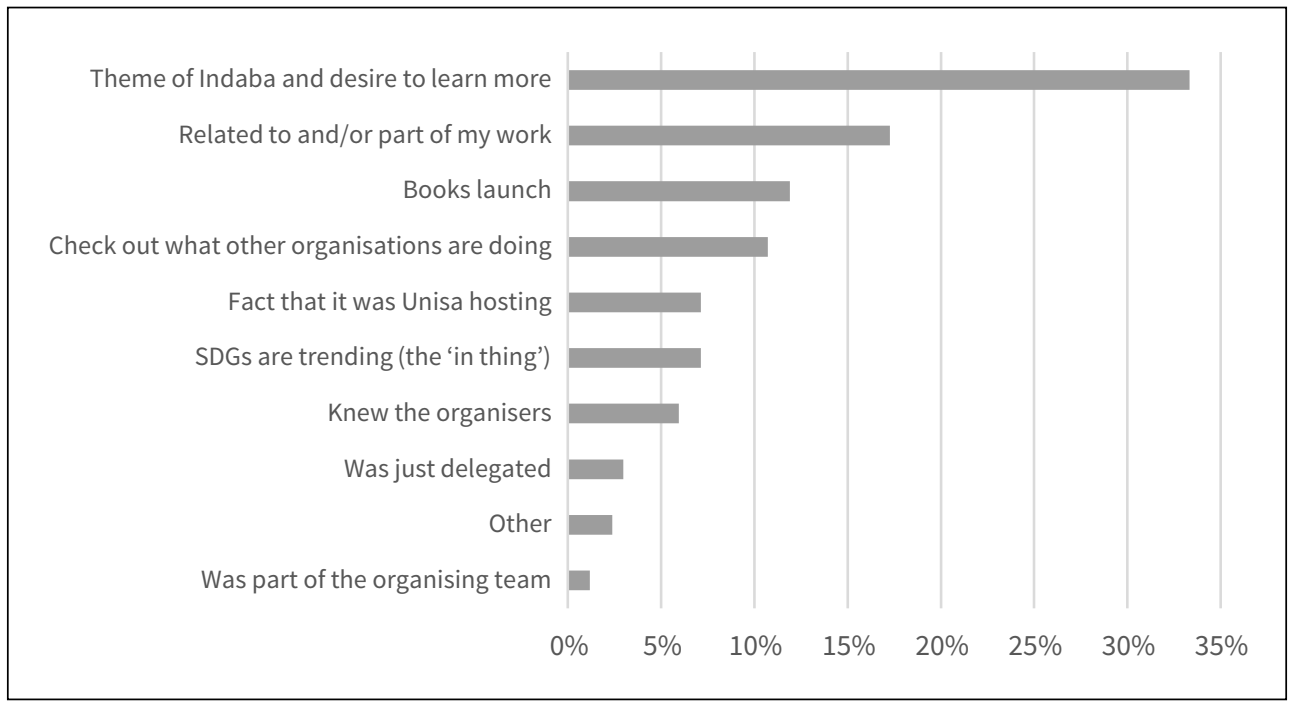

The participants were further asked to express an opinion on whether the concept of SDGs localisation in higher education is one that all universities in South Africa and worldwide should implement. The findings are indicated in Figure 5. All 72 respondents answered in the affirmative, with $73 \%$ indicating they strongly agreed. This response challenges all institutions of higher education to do more to localise the SDGs. However, when asked to reveal whether certain participants' institutions (higher education or not) had localised the SDGs, there was a low affirmative response. Only 30\% indicated that their institutions had done so, with $32 \%$ responding they had not. The remaining $38 \%$ indicated they were 'not sure'. A more personal question was also included to gauge the participants' familiarity with and reading of the United Nations document Transforming Our World: The 2030 Agenda for Sustainable Development prior to the Unisa SDGs Indaba. A disappointing $47 \%$ of the respondents revealed they were not familiar with the document. This was a cause for concern, especially since $58 \%$ of the respondents were in the academic space (academic staff $-43 \%$ and students $-15 \%)$. 
Figure 5: Should all universities in South Africa and worldwide localise SDGs? Source: Author

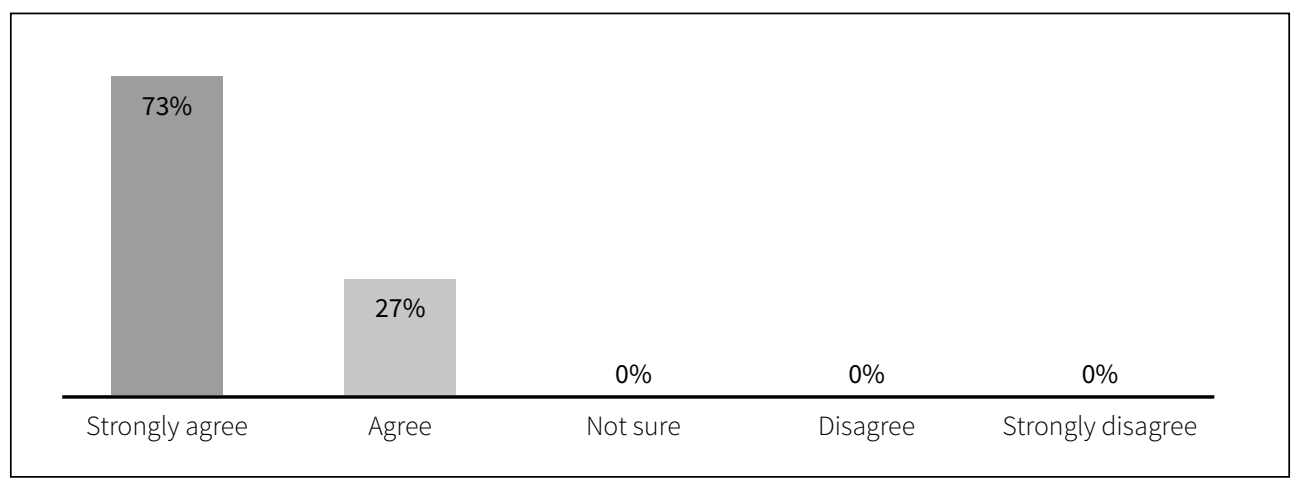

Following the hosting of the SDGs Localisation Indaba, several responses were posted on social media. Some were sent to the author and these are discussed briefly below. There was general consensus that the SDGs Localisation Indaba was highly insightful, impressive and valuable. The Indaba was also viewed as an extremely informative and exciting forum. One respondent wrote: "I left Unisa intellectually richer today" and committed to working towards pushing SDGs localisation in the Technical, Vocational Education and Training (TVET) colleges' space. The same line of interest and enrichment was evident in a response from one Unisa non-academic staff member who claimed that the SDGs Localisation Indaba had generated interest in the topic and that they were now committed to learning more and becoming more involved. One participant from a district municipality posted a segment of the SDGs Localisation Indaba on their Facebook page. The response to the posting was heartening as a group of youth stated they that did not want to be left behind. In their request, the representative of the youth group wrote the following:

We would like to partner with Unisa on the SDGs localisation project. Our organisation is called the South African Youth Centre for Climate Change. We [have] just had our local youth conference in Durban and have delegates attending COP25 in Madrid.

There were an additional 49 responses to the open-ended question in the survey that asked participants to make any observations about the event. A breakdown of the responses is shown in Figure 6. What emerged is that the SDGs Localisation in Higher Education InstitutionsIndaba was helpful and those who commented, wished to see more of the same and longer events (the Indaba was only half a day). A call was also made to involve more stakeholders. In the words of one respondent: "Personally, I did not see the involvement of chemist[s], physicist[s], and othersparticularly from natural science." Another participant raised similar concerns: "I wish some of my colleagues could have attended so that we continue with this conversation". 
Figure 6: Responses to the open-ended question requesting comments $(n=49)$. Source: Author

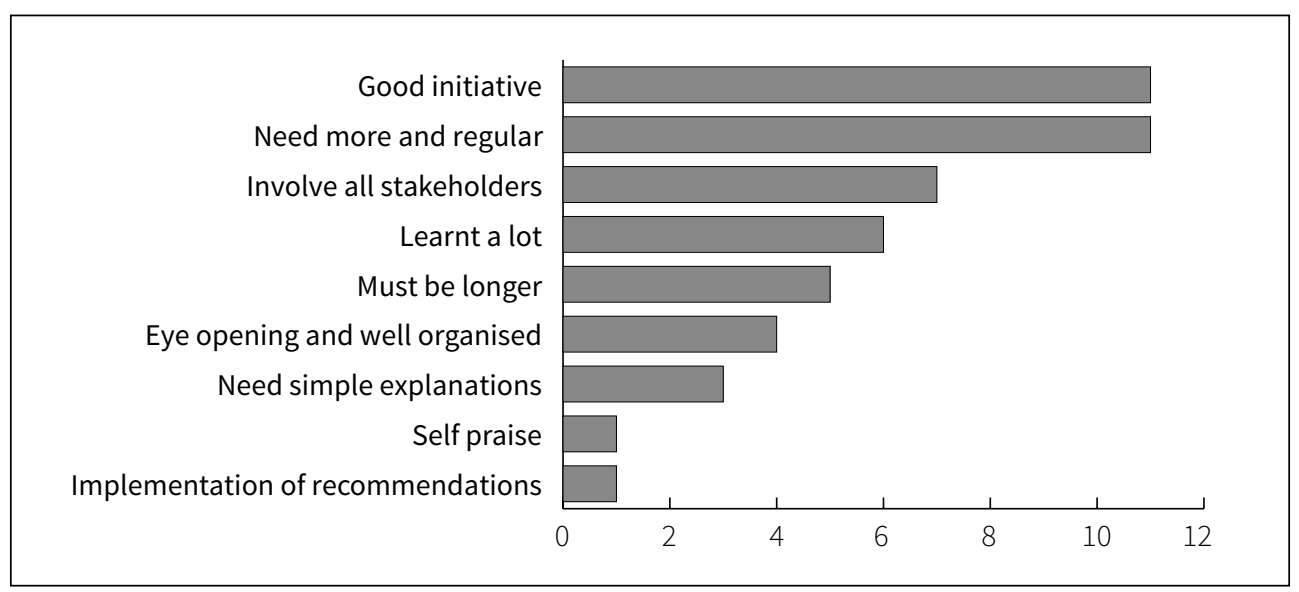

Some participants indicated that they had scant knowledge of the SDGs prior to their participation in the Indaba. Ongoing SDGs Indabas were proposed including tracking of progress. One participant noted while the Indaba had provided some great inputs, of concern was its sustainability in terms of implementing the recommendations, involving all key stakeholders from academia to communities and student, and the design of inter- and transdisciplinary modules and programmes. A call was made to broaden the SDGs Indaba to include the entire higher education ecosystem, including the TVET colleges in South Africa, which are lagging behind. One respondent requested the creation of a platform to assist the understanding and implementation of the SDGs, including a plan to roll out the SDGs localisation programmes to other institutions, as well as to all spheres of government in South Africa (national, provincial and local).

\section{Conclusions}

This paper describes the processes leading to the Unisa SDGs Localisation Indaba in November 2019. What started as an in-reach community engagement project ultimately embraced the whole institution, all SDGs and the wider South African higher education sector. Three clear cycles could be identified, namely the development of a Unisa management policy brief calling for an SDGs Localisation Indaba in 2017 (Cycle 1); the development of an SDGs for Society research stream under the Unisa Annual Interdisciplinary Academy and Summer School in 2018 (Cycle 2); and the SDGs Localisation Indaba in 2019 (Cycle 3). The findings revealed that apart from hosting a successful Indaba, Unisa was responsible for two additional achievements, namely the conclusion of a Unisa SDGs Localisation Declaration, and the decision to file for THE Impact Ranking in December 2019. The Declaration was ranked highly by participants. The Declaration was also responsible for the formation of a key institution, the SDGs Liaison Committee. Furthermore, several actions were agreed upon to expand the localisation of SDGs at Unisa. Lastly, the Indaba attracted 
many participants from outside Unisa, especially from other higher education institutions, some of whom suggested the SDGs Indaba be held annually.

The primaryrecommendation from this paper is that those championingSDGslocalisation should be prepared to continue pushing as management changes and processes are often delayed for long periods. It took almost three years to realise the SDGs localisation dream at Unisa. Hence, drawing from the literature and discussions, perspectives on institutional work, actors and stakeholder contestations, political power, and incremental transition to sustainability should all be further considered. For example, the creation of both an online and offline space for collaboration, building relationships between stakeholders that promote an enabling environment for active participation and engagement with citizens, and the incorporation of cultural dimensions from the Madrid project remain learning points. It is important to note that the COVID-19 pandemic stalled much of the progress towards the implementation of the SDGs Localisation Declaration. For an entire year, staff were working from home and some continue to do so. While progress has been made, movement in terms of commissioning the SDGs Champions was only evident in the second quarter of 2020. Plans are also under way to monitor the implementation of the SDGs localisation through identified measurable indicators, some drawn from the general United Nations SDGs indicators' framework. Thus, despite the work to date on SDGs localisation, more ongoing work is required at Unisa and other higher education institutions.

\section{Notes on Contributor}

Nhamo, Godwell

Godwell Nhamo is a Full Professor and Exxaro Chair in Climate and Sustainability Transitions at the University of South Africa and holds a PhD from Rhodes University. He has published 17 books ( 4 edited and 13 co-authored) and 101 journal articles.

\section{References}

Akins II, E., Giddens, E., Glassmeyer, D., Gruss, A., Hedden, M.K., Slinger-Friedman, V. \& Weand, M. (2019). Sustainability education and organizational change: A critical case study of barriers and change drivers at a higher education institution. Sustainability, 11, 501. doi:10.3390/su11020501.

Alejandro-Cruz, J.S., Rio-Belver, R.M., Almanza-Arjona, Y.C. \& Rodriguez-Andara, A. (2019). Towards a science map on sustainability in higher education. Sustainability, 11, 3521. doi:10.3390/su11133521.

Bartlett, P.W., Popov, M. \& Ruppert, J. (2019). Integrating core sustainability metacompetencies and SDGs across the silos in curriculum and professional development. In G. Nhamo \& V. Mjimba (Eds.), Sustainable Development Goals and Institutions of Higher Education: Sustainable development goals series. doi:10.1007/978-3-030-261573_6. 
Beunen, R. \& Patterson, J.J. (2019). Analysing institutional change in environmental governance: exploring the concept of 'institutional work'. Journal of Environmental Planning and Management, 62(1), 12-29. doi: 10.1080/09640568.2016.1257423.

Dedeurwaerdere, T. (2013). Transdisciplinary Sustainability Science at Higher Education Institutions: Science Policy Tools for Incremental Institutional Change. Sustainability, 5, 3783-3801. doi:10.3390/su5093783.

De Paula Arruda Filho, N., Hino, M.C. \& Beuter, B.S.P. (2019). Including SDGs in the education of globally responsible leaders. International Journal of Sustainability in Higher Education, 20(5), 856-870. doi 10.1108/IJSHE-01-2019-0032.

DITOs Consortium. (2017). Citizen Science and Open Science: Synergies and future areas of work. DITOS (Doing It Together Open Science) Policy Brief 3. Open Innovation, Open Science and Open to the World - A Vision for Europe. Luxembourg: Publications Office of the European Union.

El-Jardali, F., Ataya, N. \& Fadlallah, R. (2018). Changing roles of universities in the era of SDGs: Rising up to the global challenge through institutionalising partnerships with governments and communities. Health Research Policy Systems, 16, 38. doi:10.1186/ s12961-018-0318-9.

Farinha, C., Caeiro, S. \& Azeiteiro, U. (2019). Sustainability strategies in portuguese higher education institutions: Commitments and practices from internal insights. Sustainability, 11, 3227. doi:10.3390/su11113227.

Filho, W.L., Shiel, C., Paço, A., Mifsud, M., Avila, L.V., Brandli, L.L., Molthan-Hill, P., Pace, P., Azeiteiro, U.M., Vargas, V.R. \& Caeiro, S. (2019). Sustainable development goals and sustainability teaching at universities: Falling behind or getting ahead of the pack? Journal of Cleaner Production, 232, 285-294. doi:10.1016/j.jclepro.2019.05.309.

Findler, F., Schönherr, N., Lozano, R. \& Stacherl, B. (2019). Assessing the impacts of higher education institutions on sustainable development: An analysis of tools and indicators. Sustainability, 11, 59. doi:10.3390/su11010059.

Fleaca, E., Fleaca, B. \& Maiduc, S. (2018). Aligning strategy with sustainable development goals (SDGs): Process scoping diagram for entrepreneurial higher education institutions (HEIs). Sustainability, 10, 1032. doi:10.3390/su10041032.

Franco, I., Saito, O., Vaughter, P., Whereat, J., Kanie, N. \& Takemoto, K. (2019). Higher education for sustainable development: Actioning the global goals in policy, curriculum and practice. Sustainability Science, 14, 1621-1642. doi:10.1007/s11625018-0628-4.

Ketlhoilwe, M.J., Silo, N., \& Velempini, K. (2020). Enhancing the roles and responsibilities of higher education institutions in implementing the sustainable development goals. In G. Nhamo, \& V. Mjimba (Eds.), Sustainable Development Goals and Institutions of Higher Education: Sustainable development goals series. doi:10.1007/978-3-030-261573_10. 
Kioupi, V. \& Voulvoulis, N. (2019). Education for Sustainable Development: A systemic framework for connecting the SDGs to educational outcomes. Sustainability, 11, 6104. doi:10.3390/su11216104.

Kopnina, H. (2018). Teaching sustainable development goals in The Netherlands: A critical approach. Environmental Education Research, 24(9), 1268-1283. doi:10.1080/1350462. 2017.1303819.

Korhonen-Kurki, K., Koivuranta, R., Kuitto, V., Pietikäinen, J. \& Schönach, P. (2020). Towards realising SDGs in the University of Helsinki. In G. Nhamo \& V. Mjimba (Eds.), Sustainable Development Goals and Institutions of Higher Education: Sustainable development goals series. doi:10.1007/978-3-030-26157-3_2.

Kupika, O.L., Mbereko, A. \& Chinokwetu, V. (2020). Role of universities towards achieving climate change-related SDGs: Case of Chinhoyi University of Technology, Zimbabwe. In G. Nhamo \& V. Mjimba (Eds.), Sustainable Development Goals and Institutions of Higher Education: Sustainable development goals series. doi:10.1007/978-3-030-261573_8.

Mataix, C., Lumbreras, J., Romero, S., Alméstar, M., Moreno, J., Mazorra, J., Kennedy, J., Bachmann, A., Azcárate, J., Cristóbal, Á. \& Ferré, R. (2020). Opportunity to foster urban innovation through universities: The case of Madrid. In G. Nhamo \& V. Mjimba (Eds.), Sustainable Development Goals and Institutions of Higher Education: Sustainable development goals series. doi:10.1007/978-3-030-26157-3_9.

McAteer, M. \& Wood, L. (2018). Decolonising knowledge: Enacting the civic role of the university in a community-based Project. South African Journal of Education, 38(4), 1662. doi: 10.15700/sajee.v38n4a1662.

Milchram, C., Märker, C., Schlör, H., Künneke, R. \& Van de Kaa, G. (2019). Understanding the role of values in institutional change: The case of the energy transition. Energy, Sustainability and Society, 9, 46. doi: 10.1186/s13705-019-0235-y.

Nhamo, G. (2012). Participatory action research as a platform for community engagement in higher education. Journal of Higher Education in Africa, 10(1), 1-20.

Nhamo, G. (2017). New global sustainable development agenda: A focus on Africa. Sustainable Development, 25, 227-241. doi:10.1002/sd.1648.

Nhamo, G. (2020). Higher education and the energy sustainable development goal: Policies and projects from University of South Africa. In G. Nhamo \& V. Mjimba (Eds.), Sustainable Development Goals and Institutions of Higher Education: Sustainable development goals series. doi:10.1007/978-3-030-26157-3_3.

Nhamo, G. \& Mjimba, V. (2020). The context: SDGs and institutions of higher education. In G. Nhamo \& V. Mjimba (Eds.), Sustainable Development Goals and Institutions of Higher Education: Sustainable development goals series. doi:10.1007/978-3-030-261573_1.

Owens, T.L. (2017). Higher education in the sustainable development goals framework. European Journal of Education, 52: 414-420. doi:10.1111/ejed.12237. 
Paletta, A., Fochi, P., Toschi, T.G. \& Ubertini, F. (2020). Adoption of the SDGs as a reporting framework at the Alma Mater Studiorum (University of Bologna) in Italy. In G. Nhamo \& V. Mjimba (Eds.), Sustainable Development Goals and Institutions of Higher Education: Sustainable development goals series. doi:10.1007/978-3-030-26157-3_15.

Parkes, C., Buono, A.F. \& Howaidy, G. (2017). The principles for responsible management education (PRME): The first decade - What has been achieved? The next decade Responsible management education's challenge for the sustainable development goals (SDGs). International Journal of Management Education, 15, 61-65.

Paul, S. (2020). University environmental hackathons to further the sustainable development goals. In G. Nhamo \& V. Mjimba (Eds.), Sustainable Development Goals and Institutions of Higher Education: Sustainable development goals series. doi:10.1007/978-3-030-26157-3_11.

Rogers, A. (2019). Second-generation non-formal education and the sustainable development goals: Operationalising the SDGs through community learning centres. International Journal of Lifelong Education, 38(5), 515-526. doi:10.1080/02601370.201 9.1636893.

Ryan, C. \& Squires, G. (2019). Social movement research with whom: Potential contributions of community-based research methods. Research in Social Movements, Conflicts and Change, 43, 185-211. doi:0.1108/S0163-786X20190000043014.

Simsekoglu, Ö. \& Klöckner, C. (2019). Factors related to the intention to buy an e-bike: A survey study from Norway. Transportation Research Part F, 60, 573-581. doi:10.1016/j.trf.2018.11.008.

Ukenna, S.I., Idoko, E.C. \& Ogbari, M.E. (2018). Drivers of sustainable consumption in a developing Sub-Saharan African setting: Nigerian academic staff perspective. International Journal of Sustainable Society, 10(3), 203-224.

University of South Africa. (2019). Unisa SDGs Localisation Declaration. Pretoria: University of South Africa.

United Nations. (2015). Transforming our World: The 2030 Agenda for Sustainable Development. New York: United Nations Secretariat.

Van Staden, W. (2020). Climate responsive innovation within the agricultural curriculum and learning system. Southern African Journal of Environmental Education, 36, 73-87. doi:10.4314/sajee.v36i1.6

Verhulst, E. \& Boks, C. (2014). Employee empowerment for sustainable design. Journal of Corporate Citizenship, 55, 73-101.

Villa, E., Valencia, D.C., Valencia-Arias, A., Hormechea, K. \& García, J. (2020). Transformative innovation policy, SDGs, and the Colombian University. In G. Nhamo \& V. Mjimba (Eds.), Sustainable Development Goals and Institutions of Higher Education: Sustainable development goals series. doi:10.1007/978-3-030-26157-3_14.

Vladimirova, K. \& Le Blanc, D. (2016). Exploring links between education and sustainable development goals through the lens of UN flagship reports. Sustainable Development, 24, 254-271. doi:10.1002/sd.1626. 
Weybrecht, G. (2017). From challenge to opportunity. Management education's crucial role in sustainability and the sustainable development goals: An overview and framework. International Journal of Management Education, 15, 84-92. doi:10.1016/j.ijme.2017.02.008.

Wood, L. (2019). PALAR: Participatory action learning and action research for community engagement. In O. Zuber-Skerritt \& L. Wood (Eds.), Action learning and action research: Genres and approaches. Bingley, UK: Emerald. pp.193-206. doi:10.1108/978-1-78769537-520191017.

Wu, J., Liao, H., Wang, J W. \& Chen, T. (2019). The role of environmental concern in the public acceptance of autonomous electric vehicles: A survey from China. Transportation Research Part F, 60, 37-46. doi:10.1016/j.trf.2018.09.029.

Zhou, L., Rundumbu, N., Shumba, J. \& Olumide, A. (2020). Role of higher education institutions in the implementation of sustainable development goals. In G. Nhamo \& V. Mjimba (Eds.), Sustainable Development Goals and Institutions of Higher Education: Sustainable development goals series. doi:10.1007/978-3-030-26157-3_7.

\section{Endnotes}

1 Indaba refers to Zulu and Xhosa tribal gatherings to deliberate on important matters in society. Such Indabas have found space and recognition in modern South African organisations including universities, political parties, and companies.

2 Colleges are similar to faculties in other university configurations. 